\title{
Phosphido-Bis(Borane) Complexes of the Alkaline Earth Metals $\dagger$
}

\author{
Keith Izod,* James M. Watson, Ross W. Harrington, William Clegg
}

Main Group Chemistry Laboratories, School of Chemistry, Newcastle University, Newcastle upon Tyne, NE1 7RU, UK

† Electronic supplementary information (ESI) available: Crystallographic refinement details; NMR spectroscopic data. CCDC 2023940-2023944. For ESI and crystallographic data in CIF or other electronic format see DOI: 10.1039/xxxxxxxxxx 


\begin{abstract}
The reaction between two equivalents of $\left\{\left(\mathrm{Me}_{3} \mathrm{Si}\right)_{2} \mathrm{CH}\right\}(\mathrm{Ph}) \mathrm{PH}\left(\mathrm{BH}_{3}\right)(\mathbf{1})$ and $\mathrm{Bu}_{2} \mathrm{Mg}$, followed by two equivalents of $\mathrm{BH}_{3} \cdot \mathrm{SMe}_{2}$, gives the corresponding phosphido-bis(borane) complex, which may be crystallised as two distinct chemical species: the complex $\left[\left\{\left(\mathrm{Me}_{3} \mathrm{Si}\right)_{2} \mathrm{CH}\right\}(\mathrm{Ph}) \mathrm{P}\left(\mathrm{BH}_{3}\right)_{2}\right]_{2} \mathrm{Mg}(\mathrm{THF})_{4} \cdot \mathrm{THF}(\mathbf{2 a})$, and two different THF solvates $(1: 1$ and 1:2) of the solvent-separated ion triples $\left[\left\{\left(\mathrm{Me}_{3} \mathrm{Si}\right)_{2} \mathrm{CH}\right\}(\mathrm{Ph}) \mathrm{P}\left(\mathrm{BH}_{3}\right)_{2}\right]_{2}\left[\mathrm{Mg}(\mathrm{THF})_{6}\right] \cdot \mathrm{THF}(\mathbf{2 b})$ and $\left[\left\{\left(\mathrm{Me}_{3} \mathrm{Si}\right)_{2} \mathrm{CH}\right\}(\mathrm{Ph}) \mathrm{P}\left(\mathrm{BH}_{3}\right)_{2}\right]_{2}\left[\mathrm{Mg}(\mathrm{THF})_{6}\right] \cdot 2 \mathrm{THF}(2 \mathrm{c})$. Similar reactions between two equivalents of 1 and either (4-tBuC$\left.{ }_{6} \mathrm{H}_{4}-2-\mathrm{CH}_{2}\right)_{2} \mathrm{Ca}(\mathrm{THF})_{4}$ or $\left[\left(\mathrm{Me}_{3} \mathrm{Si}\right)_{2} \mathrm{CH}\right]_{2} \mathrm{Sr}(\mathrm{THF})_{2}$, followed by two equivalents of $\mathrm{BH}_{3} \cdot \mathrm{SMe}_{2}$, give the heavier alkali metal complexes $\left[\left\{(\mathrm{Me} 3 \mathrm{Si})_{2} \mathrm{CH}\right\}(\mathrm{Ph}) \mathrm{P}\left(\mathrm{BH}_{3}\right)_{2}\right]_{2} \mathrm{M}(\mathrm{THF})_{4}[\mathrm{M}=\mathrm{Ca}$ (3), Sr (4)]. Surprisingly, compounds 2a, 3 and $\mathbf{4}$ adopt almost identical structures in the solid state, which differ only in the geometrical arrangement of the phosphido-borane ligands and the hapticity of the borane groups.
\end{abstract}

\title{
Introduction
}

Although the product of the reaction between $\mathrm{PH}_{3}$ and diborane was originally proposed by Gamble and Gilmont to have the structure $\mathrm{PH}_{4}\left[\mathrm{H}_{2} \mathrm{P}\left(\mathrm{BH}_{3}\right)_{2}\right]$ in 1940 , ${ }^{1}$ the first unambiguous complex of a phosphido-bis(borane) anion $\left[\mathrm{R}_{2} \mathrm{P}\left(\mathrm{BH}_{3}\right)_{2}\right]^{-}$(also known as a phosphinodiboranate anion) was isolated in 1965: the reaction of $\mathrm{KPR}_{2}(\mathrm{R}=\mathrm{H}, \mathrm{Me})$ with diborane in diethyl ether was shown to give the corresponding phosphido-bis(borane) salts $\mathrm{K}\left[\mathrm{R}_{2} \mathrm{P}\left(\mathrm{BH}_{3}\right)_{2}\right] .^{2}$ The corresponding lithium and sodium derivatives were isolated a few years later and their composition was confirmed by multinuclear NMR spectroscopy. ${ }^{3}$

In spite of these early forays, phosphido-bis(borane) anions have not been the subject of detailed studies and little is known about their coordination chemistry: until very recently, structurally characterised examples were limited to only a handful of alkali metal complexes. ${ }^{4}$ This is particularly surprising in light of the relatively well-developed coordination chemistry 
of the corresponding nitrogen-based aminodiboranate anions $\left[\mathrm{R}_{2} \mathrm{~N}\left(\mathrm{BH}_{3}\right)_{2}\right]^{-}$, which act as chelating and/or bridging ligands for a range of metals, including group 1, 2, lanthanide, and actinide ions. $^{5}$

Nonetheless, there is increasing interest in these ligands and, in addition to their alkali metal complexes, phosphido-bis(borane) anions have recently been used for the synthesis of a series of lanthanide and uranium(III) complexes. ${ }^{6}$ Very recently, a single example of an alkaline earth metal complex of a phosphido-bis(borane) ligand was reported by Hill, Mahon, Manners and co-workers: treatment of the phosphido-borane complex [(BDI) Mg $\left.\left\{\mathrm{Ph}_{2} \mathrm{P}\left(\mathrm{BH}_{3}\right)\right\}\right]_{2}$ with two equivalents of $\mathrm{Ph}_{2} \mathrm{PH}\left(\mathrm{BH}_{3}\right)$ was found not to lead to hydride elimination as expected, but instead gave the phosphido-bis(borane) bridged dimer $\left[(\mathrm{BDI}) \mathrm{Mg}\left\{\mathrm{Ph}_{2} \mathrm{P}\left(\mathrm{BH}_{3}\right)_{2}\right\}\right]_{2}$ via a borane exchange reaction $[\mathrm{BDI}=\mathrm{HC}\{\mathrm{CMeN}(2,6-$ $\left.\left.\left.i \operatorname{Pr}_{2} \mathrm{C}_{6} \mathrm{H}_{3}\right)\right\}_{2}\right] .{ }^{7}$

Structural studies have established three principal phosphido-bis(borane) ligand coordination modes, each involving one or more B-H $\cdots \mathrm{M}$ contacts: chelating (I), bridging (II) and “dangling” modes (III). The coordination mode adopted is determined by the nature of the metal centre and the presence of any additional donor ligands. For example, the dimeric complexes $\left\{t \mathrm{Bu}_{2} \mathrm{P}\left(\mathrm{BH}_{3}\right)_{2}\right\}_{2} \mathrm{Ln}\left\{\mu-t \mathrm{Bu}_{2} \mathrm{P}\left(\mathrm{BH}_{3}\right)_{2}\right\}_{2} \mathrm{Ln}\left\{t \mathrm{Bu}_{2} \mathrm{P}\left(\mathrm{BH}_{3}\right)_{2}\right\}_{2}[\mathrm{Ln}=\mathrm{Er}, \mathrm{Tb}, \mathrm{Lu}]$, which contain both chelating and bridging ligands, are isolated in the absence of donor solvents, irrespective of the size of the $\mathrm{Ln}^{3+}$ ion. In contrast, crystallisation of these compounds in the presence of THF yields the adducts $\left\{t \mathrm{Bu}_{2} \mathrm{P}\left(\mathrm{BH}_{3}\right)_{2}\right\}_{3} \mathrm{Ln}(\mathrm{THF})_{3}$, containing three “dangling” phosphido-bis(borane) ligands.

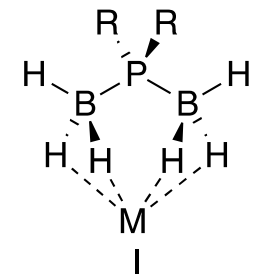

I<smiles>[R]P([R])B(BBC)B1C[M]#CC1</smiles>

II<smiles>[R][PH]([R])(B([B])[B])B([B])PC#[M]</smiles>

III 
In order to explore further the coordination chemistry of this fascinating class of ligand, we have prepared a series of alkaline earth metal complexes of the phosphidobis(borane) anion $\left[\left\{\left(\mathrm{Me}_{3} \mathrm{Si}\right)_{2} \mathrm{CH}\right\}(\mathrm{Ph}) \mathrm{P}\left(\mathrm{BH}_{3}\right)_{2}\right]^{-}$, for which we have previously isolated a series of alkali metal complexes. ${ }^{4 \mathrm{~b}}$ Somewhat unexpectedly, these adopt very similar structures in the solid state, in spite of the very large increases in ionic radii down the group from $\mathrm{Mg}^{2+}$ to $\mathrm{Ca}^{2+}$ and $\mathrm{Sr}^{2+}$.

\section{Results and Discussion}

While metathesis reactions between alkali metal phosphido-bis(borane) salts and lanthanide and actinide metal halides have been shown to yield the corresponding f-element phosphido-bis(borane) complexes, it is notable that, using this methodology, these compounds were isolated in only low-to-moderate yields (15-43\%). ${ }^{6 a}$ The low yields in these reactions were attributed to attenuated salt metathesis reactivity in the donor solvents (THF or $\mathrm{Et}_{2} \mathrm{O}$ ) required for these reactions to proceed, possibly reflecting the weak $\mathrm{B}-\mathrm{H} \cdots \mathrm{M}$ interactions in the products and the low nucleophilicity of these anions. It has subsequently been shown that a solvent-assisted mechanochemical route provides significantly higher yields of these compounds. ${ }^{6 b}$

We have found that similar reactions between the alkali metal complexes $\left[\left\{\left(\mathrm{Me} \mathrm{Si}_{2}\right)_{2} \mathrm{CH}\right\}(\mathrm{Ph}) \mathrm{P}\left(\mathrm{BH}_{3}\right)_{2}\right] \mathrm{M}[\mathrm{M}=\mathrm{Li}, \mathrm{K}]$ and alkaline earth metal diiodides also do not proceed cleanly and give only poor yields of impure alkaline earth metal phosphidobis(borane) compounds. In contrast, the reaction between the secondary phosphine-borane $\left\{\left(\mathrm{Me}_{3} \mathrm{Si}\right)_{2} \mathrm{CH}\right\}(\mathrm{Ph}) \mathrm{PH}\left(\mathrm{BH}_{3}\right)(\mathbf{1})^{4 \mathrm{~b}}$ and a suitable diorgano-alkaline earth metal complex, followed by treatment of the intermediate phosphido-borane complex with $\mathrm{BH}_{3} \cdot \mathrm{SMe}_{2}$, gives the corresponding phosphido-bis(borane) complexes in good yields. Thus, the reaction between $n \mathrm{Bu}_{2} \mathrm{Mg}$ and two equivalents of $\mathbf{1}$ in toluene gives the intermediate 
$\left[\left\{\left(\mathrm{Me}_{3} \mathrm{Si}\right)_{2} \mathrm{CH}\right\}(\mathrm{Ph}) \mathrm{P}\left(\mathrm{BH}_{3}\right)\right]_{2} \mathrm{Mg}$, which was not isolated, but which reacts in situ with two equivalents of $\mathrm{BH}_{3} \cdot \mathrm{SMe}_{2}$ in toluene/THF to give the magnesium complex $\left[\left\{\left(\mathrm{Me}_{3} \mathrm{Si}\right)_{2} \mathrm{CH}\right\}(\mathrm{Ph}) \mathrm{P}\left(\mathrm{BH}_{3}\right)_{2}\right]_{2} \mathrm{Mg}(\mathrm{THF})_{4}(2)$ (Scheme 1). This compound was isolated as single crystals of the solvate $\left[\left\{\left(\mathrm{Me}_{3} \mathrm{Si}\right)_{2} \mathrm{CH}\right\}(\mathrm{Ph}) \mathrm{P}\left(\mathrm{BH}_{3}\right)_{2}\right]_{2} \mathrm{Mg}(\mathrm{THF})_{4} \cdot \mathrm{THF}(\mathbf{2 a})$ after concentration and cooling of the reaction solution. Two further modifications of this compound, 1:1 and 1:2 THF solvates (2b and 2c, respectively) of the separated ion triple $\left[\left\{\left(\mathrm{Me}_{3} \mathrm{Si}\right)_{2} \mathrm{CH}\right\}(\mathrm{Ph}) \mathrm{P}\left(\mathrm{BH}_{3}\right)_{2}\right]_{2}\left[\mathrm{Mg}(\mathrm{THF})_{6}\right]$, were isolated from subsequent crystallisations of separate batches of 2 under similar conditions. The difference in coordination by THF and the degree of solvent in the crystal structure is presumably a function of slight differences in concentration and other conditions in the crystallisation process. For all these compounds the solvent of crystallisation, and for $\mathbf{2} \mathbf{b}$ and $\mathbf{2 c}$ the additional two equivalents of THF coordinated to the Mg centres, are only weakly held and are readily lost on exposure of the crystals to vacuum, such that this extra solvent is not observed in the elemental analyses and NMR spectra of these compounds, which are identical to those of 2.

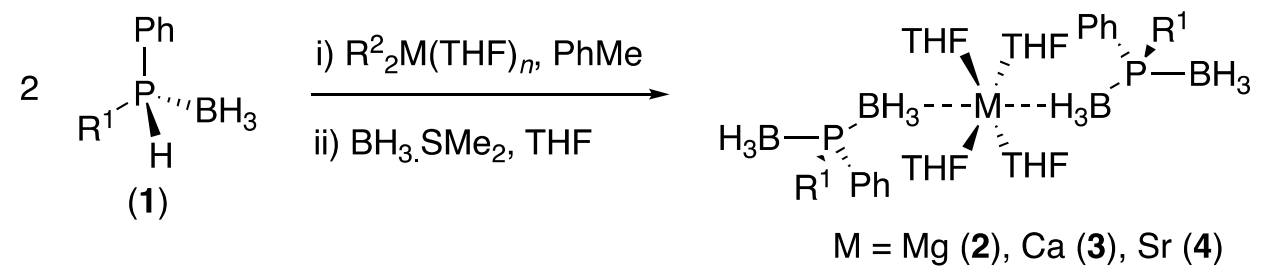

Scheme 1. $\mathrm{R}^{1}=\left(\mathrm{Me}_{3} \mathrm{Si}\right)_{2} \mathrm{CH}$.

Similarly, treatment of either $\left(4-t \mathrm{BuC}_{6} \mathrm{H}_{4} \mathrm{CH}_{2}\right)_{2} \mathrm{Ca}(\mathrm{THF})_{4}$ or $\left\{\left(\mathrm{Me}_{3} \mathrm{Si}\right)_{2} \mathrm{CH}\right\}_{2} \mathrm{Sr}(\mathrm{THF})_{2}$ with two equivalents of $\mathbf{1}$, followed by two equivalents of $\mathrm{BH}_{3} \cdot \mathrm{SMe}_{2}$, in THF gives the corresponding heavier alkali metal complexes $\left[\left\{\left(\mathrm{Me}_{3} \mathrm{Si}\right)_{2} \mathrm{CH}\right\}(\mathrm{Ph}) \mathrm{P}\left(\mathrm{BH}_{3}\right)_{2}\right]_{2} \mathrm{Ca}(\mathrm{THF})_{4}(3)$ and 
$\left[\left\{\left(\mathrm{Me}_{3} \mathrm{Si}\right)_{2} \mathrm{CH}\right\}(\mathrm{Ph}) \mathrm{P}\left(\mathrm{BH}_{3}\right)_{2}\right]_{2} \mathrm{Sr}(\mathrm{THF})_{4}(4)$ as colourless, crystalline solids. Compounds 3 and $\mathbf{4}$ are the first heavier alkaline earth metal complexes of a phosphido-bis(borane) ligand to be isolated.

While the solid-state structures of $\mathbf{2 a}$, $\mathbf{3}$, and $\mathbf{4}$ reveal two distinct boron environments (see below), the ${ }^{11} \mathrm{~B}\left\{{ }^{1} \mathrm{H}\right\}$ NMR spectra of these compounds in $d_{8}$-THF exhibit single, broad doublets at $-32.8,-32.4$, and $-31.5 \mathrm{ppm}$, respectively, with identical ${ }^{11} \mathrm{~B}-{ }^{31} \mathrm{P}$ coupling constants of $61 \mathrm{~Hz}$. This is consistent with any of: (i) rapid exchange between the free and bound $\mathrm{BH}_{3}$ groups within each ligand, (ii) rapid exchange of the phosphido-bis(borane) ligands between metal centres, or (iii) the formation of separated ion triples similar to $\mathbf{2 b} / \mathbf{2} \mathbf{c}$ in THF solution; it is not possible to distinguish among these processes based on the current data. The ${ }^{31} \mathrm{P}\left\{{ }^{1} \mathrm{H}\right\}$ NMR spectra of $\mathbf{2}, \mathbf{3}$, and $\mathbf{4}$ consist of broad, poorly resolved multiplets at $-11.5,-15.7$, and $-16.4 \mathrm{ppm}$, respectively, due to coupling to two quadrupolar ${ }^{11} \mathrm{~B}$ nuclei in each case $\left({ }^{11} \mathrm{~B}: I=3 / 2\right.$, nat. ab. $\left.80.1 \%\right)$. Prolonged exposure of 2 , 3 and 4 to vacuum leads to gradual loss of solvent to give compounds of formula $\left[\left\{\left(\mathrm{Me}_{3} \mathrm{Si}\right)_{2} \mathrm{CH}\right\}(\mathrm{Ph}) \mathrm{P}\left(\mathrm{BH}_{3}\right)_{2}\right]_{2} \mathrm{M}(\mathrm{THF})_{2}$ in each case, as judged by their ${ }^{1} \mathrm{H}$ NMR spectra.

Somewhat surprisingly, compounds $\mathbf{2 a}, \mathbf{3}$, and $\mathbf{4}$ crystallise with very similar molecular structures in the solid state. However, while 2a crystallises as a THF solvate, $\mathbf{3}$ and 4 crystallise without inclusion of uncoordinated solvent and are isomorphous and isostructural with each other. The structures of $\mathbf{2 a}$, 3, and $\mathbf{4}$ are shown in Figure 1, along with selected bond lengths and angles. 


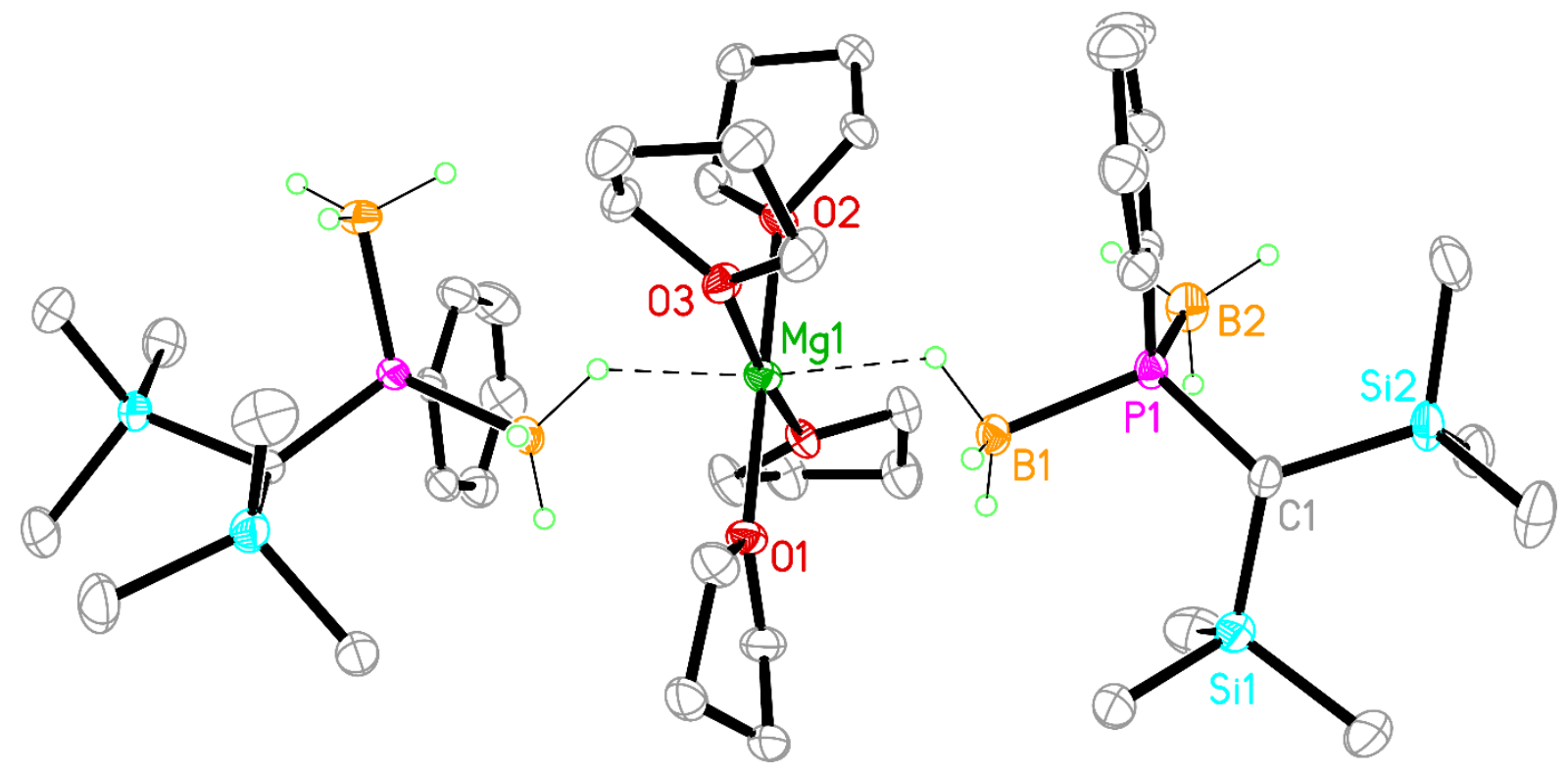

(a)

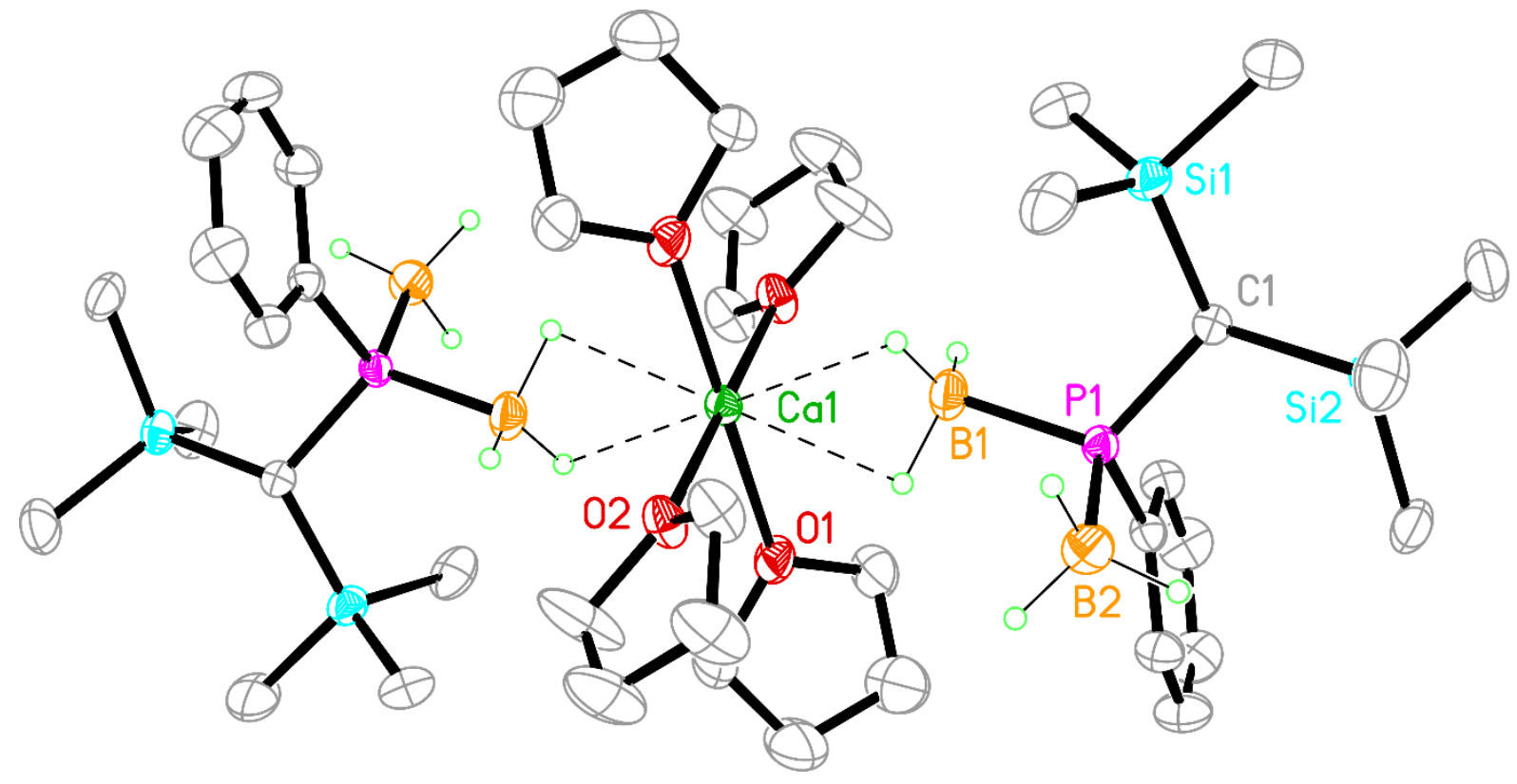

(b)

Figure 1. Molecular structures of (a) 2a and (b) 3 (which is isostructural with 4) with $40 \%$ probability ellipsoids; solvent of crystallisation, minor disorder components, and C-bound $\mathrm{H}$ atoms are omitted for clarity. Selected bond lengths ( $\AA$ ): 2a Mg1-O1 2.0510(16), Mg1-O2

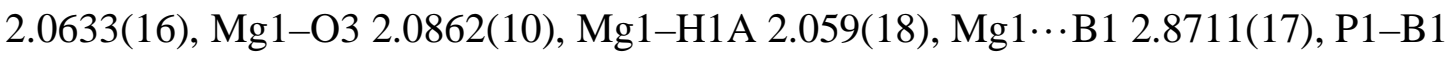
1.9448(18), P1-B2 1.9376(19), P1-C1 1.8503(15), P1-C8 1.8296(16); 3 Ca1-O1 2.405(5), 
Ca1-O2 2.372(5), Ca1-H1A 2.650(19), Ca1-H1C 2.376(19), Ca1‥B1 2.752(2), P1-B1

1.925(2), P1-B2 1.941(2), P1-C1 1.843(2), P1-C8 1.829(2); 4 Sr1-O1 2.553(7), Sr1-O2

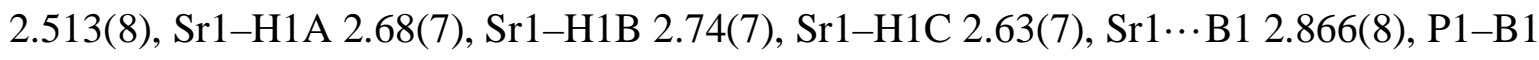

1.939(9), P1-B2 1.955(10), P1-C1 1.871(5), P1-C8 1.838(7).

All three compounds crystallise as discrete molecular species in which the metal centres are bound by one or more of the $\mathrm{H}$ atoms of one of the borane groups of each phosphido-bis(borane) ligand and the four $\mathrm{O}$ atoms of the THF co-ligands to give a transoctahedral geometry about each metal centre. The second $\mathrm{BH}_{3}$ group in each ligand has no short contacts with the metal centre; i.e. the phosphido-bis(borane) ligands adopt a “dangling” coordination mode.

The similar structures adopted by these three compounds are remarkable given the significant increase in ionic radius on going from $\mathrm{Mg}^{2+}$ to $\mathrm{Ca}^{2+}$ and $\mathrm{Sr}^{2+}(0.72,1.00$, and 1.18 $\AA$, respectively, for six-coordination), ${ }^{8}$ which would usually lead to a concomitant increase in coordination number of the metals. However, the hapticity of the $\mathrm{BH}_{3} \cdots \mathrm{M}$ contacts increases as the ionic radius of the metal centre increases, from $\eta^{1}$ in $\mathbf{2 a}$, to $\eta^{2}$ in $\mathbf{3}$ and $\eta^{3}$ in $\mathbf{4}$, which may compensate to some extent for the increasing coordination demands of the metals. Compound 2a also differs from $\mathbf{3}$ and $\mathbf{4}$ in the arrangement of its phosphido-bis(borane) ligands; in both $\mathbf{3}$ and $\mathbf{4}$ the two ligands are arranged such that there is a crystallographic inversion centre at the metal ion, whereas in 2a the two ligands are related by a $C_{2}$ axis which runs along the $\mathrm{O} 1-\mathrm{Mg}-\mathrm{O} 2$ direction, such that $\mathrm{P}-\mathrm{B}$ bonds of the "dangling” $\mathrm{BH}_{3}$ groups are oriented towards the same side of the molecule as the THF ligand containing O2.

The Mg-H1A distance of 2.059(18) $\AA$ is significantly shorter than the remaining MgH distances (3.00(3) and 3.19(3) $\AA$ ), while the Mg*B distance (2.8711(17) $\AA$ ) is 
substantially longer than the $\mathrm{Mg} \cdots \mathrm{B}$ distances found for the $\eta^{2}-\mathrm{BH}_{3} \cdots \mathrm{Mg}$ interactions in dimeric [(BDI)Mg $\left.\left\{\mathrm{Ph}_{2} \mathrm{P}\left(\mathrm{BH}_{3}\right)_{2}\right\}\right]_{2}$ (2.3973(16) and 2.4204(18) $\AA$ ), ${ }^{7}$ consistent with an unusual $\eta^{1}-\mathrm{BH}_{3} \cdots \mathrm{Mg}$ contact in 2a. The $\mathrm{Ca}-\mathrm{H}$ and $\mathrm{Ca} \cdot \cdots \mathrm{B}$ distances [2.650(19) and 2.376(19) $\AA$, and 2.752(2) $\AA$, respectively], and the $\mathrm{Sr}-\mathrm{H}$ and $\mathrm{S} r \cdots \mathrm{B}$ distances [2.68(7), 2.74(7) and 2.63(7) $\AA$, and 2.866(8) $\AA$, respectively] are typical of an $\eta^{2}-\mathrm{BH}_{3} \cdots \mathrm{Ca}$ and an $\eta^{3}-$ $\mathrm{BH}_{3} \cdots$ Sr contact, respectively. For example, the Ca $\cdots$ B distance in $\left[\left(\mathrm{Me}_{3} \mathrm{Si}\right)_{2}\left\{\mathrm{Me}_{2}\left(\mathrm{H}_{3} \mathrm{~B}\right) \mathrm{P}\right\} \mathrm{C}\right]_{2} \mathrm{Ca}(\mathrm{THF})_{4}$, which contains an $\eta^{2}-\mathrm{BH}_{3} \cdots$ Ca contact, is $2.751(2) \AA$, whereas the $\mathrm{Sr} \cdots \mathrm{B}$ distance in $\left[\left(\mathrm{Me}_{3} \mathrm{Si}\right)_{2}\left\{\mathrm{Me}_{2}\left(\mathrm{H}_{3} \mathrm{~B}\right) \mathrm{P}\right\} \mathrm{C}\right]_{2} \mathrm{Sr}(\mathrm{THF})_{5}$, where an $\eta^{3}-\mathrm{BH}_{3} \cdots \mathrm{Sr}$ contact is found, is 2.893(4) $\AA^{9}{ }^{9}$

The isolation of the separated ion triples $\mathbf{2 b}$ /2c allows a direct comparison between the structural features of isolated and coordinated phosphido-bis(borane) ligands. The structures of the anion and cation in these two modifications are essentially identical and so only $\mathbf{2} \mathbf{b}$ will be discussed here; the structure of $\mathbf{2} \mathbf{b}$ is shown in Figure 2, along with selected bond lengths and angles.
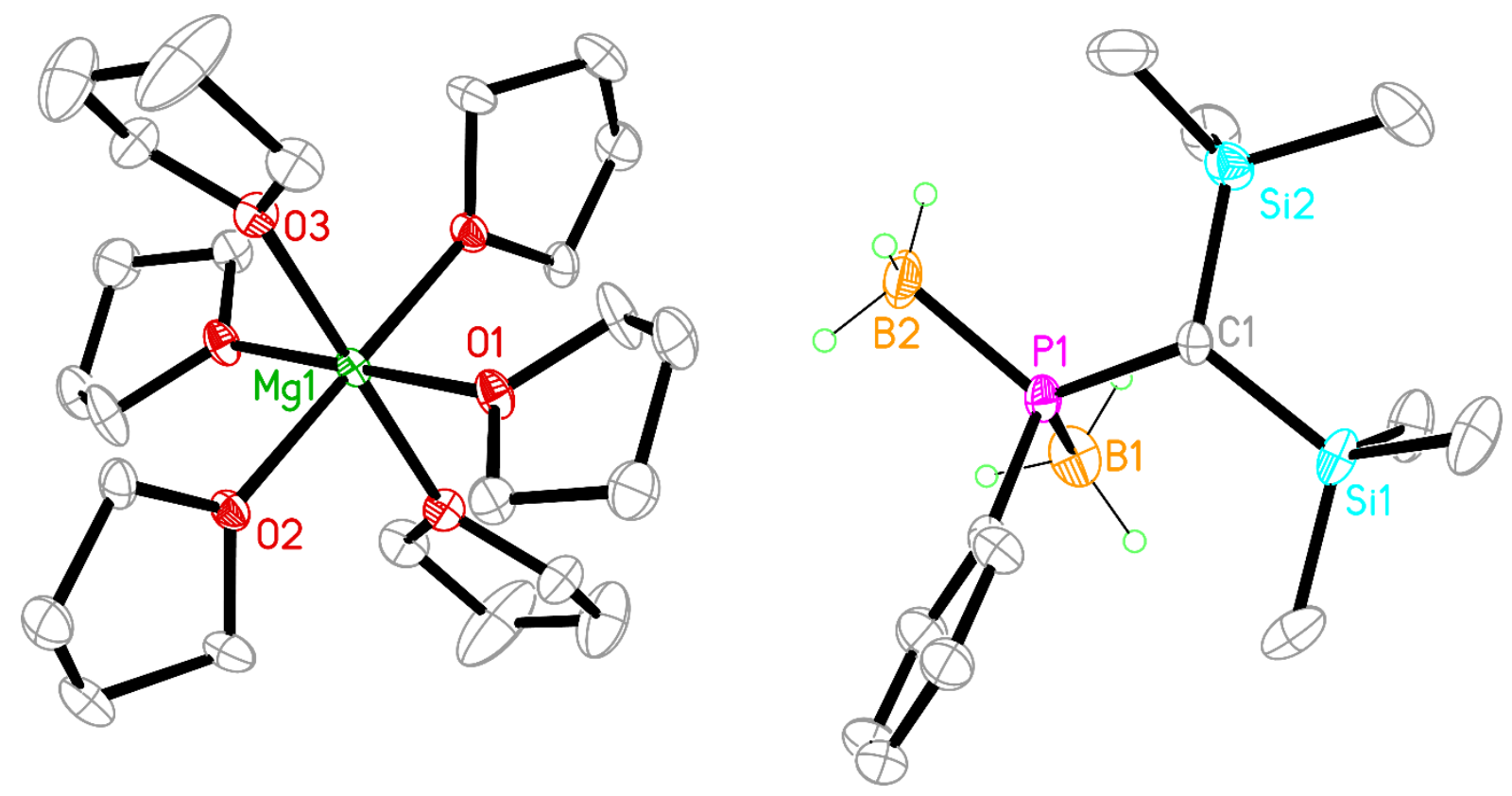
Figure 2. Solid state structure of $\mathbf{2 b}$ with $40 \%$ probability ellipsoids and with C-bound $\mathrm{H}$ atoms and uncoordinated solvent omitted for clarity. Selected bond lengths ( $\AA$ ): Mg1-O1 2.0742(11), Mg1-O2 2.0937(11), Mg1-O3 2.1115(11), P1-B1 1.946(2), P1-B2 1.938(2), P1-C1 1.8486(16), P1-C8 1.8312(19).

Examination of the $\mathrm{P}-\mathrm{B}$ distances and $\mathrm{B}-\mathrm{P}-\mathrm{B}$ angles in $\mathbf{2 a}$ and $\mathbf{2} \mathbf{b}$ shows that coordination of a single $\mathrm{BH}_{3}$ group of a phosphido-bis(borane) ligand to an alkaline earth metal has little or no impact on the skeletal structure of the anion. For example, in 2a the $\mathrm{P}-$ B distances are 1.9448(18) and 1.9376(19) $\AA$, whereas the P-B distances in 2b are 1.946(2) and 1.938(3) Å; the B-P-B angles in 2a and $\mathbf{2 b}$ are 114.39(8) and 114.16(12) ${ }^{\circ}$, respectively.

\section{Experimental Section}

All manipulations were carried out using standard Schlenk techniques under an atmosphere of dry nitrogen. Toluene and THF were dried prior to use by distillation under nitrogen from sodium or potassium, respectively; THF was stored over activated 4A molecular sieves, while toluene was stored over a potassium film. Deuterated THF was distilled from potassium under nitrogen and was deoxygenated by three freeze-pump-thaw cycles and stored over activated 4A molecular sieves. (4- $\left.\mathrm{BuC}_{6} \mathrm{H}_{4} \mathrm{CH}_{2}\right)_{2} \mathrm{Ca}(\mathrm{THF})_{4},{ }^{10}\left\{\left(\mathrm{Me}{ }_{3} \mathrm{Si}\right)_{2} \mathrm{CH}\right\}_{2} \mathrm{Sr}(\mathrm{THF})_{2},{ }^{11}$ and $\left\{\left(\mathrm{Me}_{3} \mathrm{Si}\right)_{2} \mathrm{CH}\right\}(\mathrm{Ph}) \mathrm{PH}\left(\mathrm{BH}_{3}\right)(\mathbf{1})^{4 \mathrm{~b}}$ were prepared by previously published procedures; di- $n$ butylmagnesium was purchased from Fisher as a $0.5 \mathrm{M}$ solution in heptane and $\mathrm{BH}_{3} \cdot \mathrm{SMe}_{2}$ was purchased from Aldrich as a 2.0 M solution in THF. All other compounds were used as supplied by the manufacturer. 
${ }^{1} \mathrm{H}$ spectra were recorded on a JEOL ECS500 spectrometer operating at $500.16 \mathrm{MHz}$, respectively and ${ }^{13} \mathrm{C}\left\{{ }^{1} \mathrm{H}\right\}$ spectra were recorded on a JEOL ECS400 spectrometer operating at $100.53 \mathrm{MHz}$, respectively; chemical shifts are quoted in ppm relative to tetramethylsilane. ${ }^{31} \mathrm{P}\left\{{ }^{1} \mathrm{H}\right\}$ and ${ }^{11} \mathrm{~B}\left\{{ }^{1} \mathrm{H}\right\}$ spectra were recorded on a JEOL ECS500 spectrometer operating at 202.35 and 160.16 MHz, respectively; chemical shifts are quoted in ppm relative to external 85\% $\mathrm{H}_{3} \mathrm{PO}_{4}$ and $\mathrm{BF}_{3} . \mathrm{Et}_{2} \mathrm{O}$, respectively. Elemental analyses were obtained by the Elemental Analysis Service of London Metropolitan University.

$\left[\left\{\left(\mathrm{Me}_{3} \mathrm{Si}\right)_{2} \mathbf{C H}\right\}(\mathbf{P h}) \mathbf{P}\left(\mathbf{B H}_{3}\right)_{2}\right]_{2} \mathbf{M g}(\mathrm{THF})_{4} \cdot \mathbf{T H F}(\mathbf{2 a}):$ To a solution of $\mathbf{1}(0.50 \mathrm{~g}, 1.77 \mathrm{mmol})$ in toluene $(10 \mathrm{~mL})$ was added $n \mathrm{Bu}_{2} \mathrm{Mg}(1.80 \mathrm{~mL}, 0.9 \mathrm{mmol})$ and this mixture was stirred for $1 \mathrm{~h}$. To this solution was added a solution of $\mathrm{BH}_{3} \cdot \mathrm{SMe}_{2}(0.9 \mathrm{~mL}, 1.80 \mathrm{mmol})$ and this mixture was stirred for a further $1 \mathrm{~h}$. The solution was filtered to remove a small amount of fine solid and concentrated in vacuo to ca. $5 \mathrm{~mL}$. Colourless crystals of 2a suitable for X-ray crystallography were obtained on standing at room temperature for $16 \mathrm{~h}$. Isolated crystalline yield: 0.36 g, 45\%. Anal. Calcd. for $\mathrm{C}_{42} \mathrm{H}_{92} \mathrm{~B}_{4} \mathrm{MgO}_{4} \mathrm{P}_{2} \mathrm{Si}_{4}$ (903.20): C 55.86, H 10.27\%. Found C 55.94, H 10.39\%. ${ }^{1} \mathrm{H}\left\{{ }^{11} \mathrm{~B}\right\}$ NMR (d8-THF, $\left.25{ }^{\circ} \mathrm{C}\right): \delta 0.05$ (s, 36H, SiMe $), 0.59$ (d $\left.{ }^{1} J_{\mathrm{PH}}=14.2 \mathrm{~Hz}, 2 \mathrm{H}, \mathrm{CHP}\right), 0.74\left(\mathrm{~d},{ }^{2} J_{\mathrm{PH}}=10.5 \mathrm{~Hz}, 12 \mathrm{H}, \mathrm{BH}_{3}\right), 1.77$ (m, 8H, THF), $3.61(\mathrm{~m}$, 8H, THF), 7.06-7.16 (m, 6H, ArH), 7.78 (m, 4H, ArH). ${ }^{13} \mathrm{C}\left\{{ }^{1} \mathrm{H}\right\}$ NMR $\left(d_{8}-\mathrm{THF}, 25{ }^{\circ} \mathrm{C}\right): \delta$ $4.06\left(\mathrm{SiMe}_{3}\right), 12.82$ (d, $\left.{ }^{1} J_{\mathrm{PC}}=4.8 \mathrm{~Hz}, \mathrm{CHP}\right), 26.54$ (THF), 68.38 (THF), 126.20 (ArC), $127.49\left(\mathrm{~d}, J_{\mathrm{PC}}=7.7 \mathrm{~Hz}, \mathrm{ArC}\right), 133.39\left(\mathrm{~d}, J_{\mathrm{PC}}=6.7 \mathrm{~Hz}, \mathrm{ArC}\right), 138.59(\mathrm{ArC}) .{ }^{11} \mathrm{~B}\left\{{ }^{1} \mathrm{H}\right\} \mathrm{NMR}$ $\left(d_{8}\right.$-THF, $\left.25{ }^{\circ} \mathrm{C}\right): \delta-32.8\left(\mathrm{~d}, \mathrm{br},{ }^{1} J_{\mathrm{PB}}=61 \mathrm{~Hz}\right) .{ }^{31} \mathrm{P}\left\{{ }^{1} \mathrm{H}\right\}$ NMR $\left(d_{8}\right.$-THF, $\left.25{ }^{\circ} \mathrm{C}\right): \delta-11.6(\mathrm{~m}$, br).

$\left[\left\{\left(\mathbf{M e}_{3} \mathrm{Si}\right)_{2} \mathbf{C H}\right\}(\mathbf{P h}) \mathbf{P}\left(\mathbf{B H}_{3}\right)_{2}\right]_{2} \mathbf{C a}(\mathbf{T H F})_{4}$ (3): To a solution of $\mathbf{1}(0.77 \mathrm{~g}, 2.73 \mathrm{mmol})$ in toluene $(10 \mathrm{~mL})$ was added a solution of $\left(4-t \mathrm{BuC}_{6} \mathrm{H}_{4} \mathrm{CH}_{2}\right)_{2} \mathrm{Ca}(\mathrm{THF})_{4}(0.85 \mathrm{~g}, 1.36 \mathrm{mmol})$ in THF (10 mL) and this mixture was stirred for $1 \mathrm{~h}$. To this solution was added a solution of $\mathrm{BH}_{3} \cdot \mathrm{SMe}_{2}(1.4 \mathrm{~mL}, 2.80 \mathrm{mmol})$ and this mixture was stirred for a further $1 \mathrm{~h}$. The solution 
was concentrated in vacuo until incipient crystallisation and then warmed until the product re-dissolved. Colourless crystals of $\mathbf{3}$ suitable for X-ray crystallography were obtained on standing at room temperature for $16 \mathrm{~h}$. Isolated crystalline yield: $0.85 \mathrm{~g}, 80 \%$. Anal. Calcd. for $\mathrm{C}_{42} \mathrm{H}_{92} \mathrm{~B}_{4} \mathrm{CaO}_{4} \mathrm{P}_{2} \mathrm{Si}_{4}$ (918.79): C 54.90, H 10.09\%. Found C 54.69, H 9.77\%. ${ }^{1} \mathrm{H}\left\{{ }^{11} \mathrm{~B}\right\}$ NMR (d $\left.d_{8}-\mathrm{THF}, 25^{\circ} \mathrm{C}\right): \delta 0.07\left(\mathrm{~s}, 36 \mathrm{H}, \mathrm{SiMe}_{3}\right), 0.68\left(\mathrm{~d},{ }^{2} J_{\mathrm{PH}}=15.1 \mathrm{~Hz}, 2 \mathrm{H}, \mathrm{CHP}\right), 0.72(\mathrm{~d}$, $\left.{ }^{2} J_{\mathrm{PH}}=12.9 \mathrm{~Hz}, 12 \mathrm{H}, \mathrm{BH}_{3}\right), 1.79$ (m, 8H, THF), 3.60 (m, 8H, THF), 7.15-7.19 (m, 6H, ArH), $7.76(\mathrm{~m}, 4 \mathrm{H}, \mathrm{ArH}) .{ }^{13} \mathrm{C}\left\{{ }^{1} \mathrm{H}\right\} \mathrm{NMR}\left(d_{8}\right.$-THF, $\left.25{ }^{\circ} \mathrm{C}\right): \delta 3.80\left(\mathrm{~d},{ }^{3} J_{\mathrm{PC}}=1.9 \mathrm{~Hz}, \mathrm{SiMe}_{3}\right), 12.03$ (d, $\left.{ }^{1} J_{\mathrm{PC}}=1.9 \mathrm{~Hz}, \mathrm{CHP}\right), 26.54$ (THF), 68.39 (THF), $127.92\left(\mathrm{~d},{ }^{3} J_{\mathrm{PC}}=7.7 \mathrm{~Hz}, \mathrm{ArC}\right), 128.18$ (ArC), $133.20\left(\mathrm{~d},{ }^{2} J_{\mathrm{PC}}=7.7 \mathrm{~Hz}, \mathrm{ArC}\right), 144.79\left(\mathrm{~d},{ }^{1} J_{\mathrm{PC}}=36.4 \mathrm{~Hz}, \mathrm{ArC}\right) .{ }^{11} \mathrm{~B}\left\{{ }^{1} \mathrm{H}\right\} \mathrm{NMR}\left(d_{8^{-}}\right.$ THF, $\left.25{ }^{\circ} \mathrm{C}\right): \delta-32.4\left(\mathrm{~d}, \mathrm{br},{ }^{1} J_{\mathrm{PB}}=61 \mathrm{~Hz}\right) .{ }^{31} \mathrm{P}\left\{{ }^{1} \mathrm{H}\right\}$ NMR $\left(d_{8}-\mathrm{THF}, 25{ }^{\circ} \mathrm{C}\right): \delta-15.9(\mathrm{~m}, \mathrm{br})$.

$\left[\left\{\left(\mathrm{Me}_{3} \mathrm{Si}\right)_{2} \mathbf{C H}\right\}(\mathbf{P h}) \mathbf{P}\left(\mathrm{BH}_{3}\right)_{2}\right]_{2} \mathrm{Sr}(\mathrm{THF})_{4}$ (4): To a solution of $\mathbf{1}(0.24 \mathrm{~g}, 0.84 \mathrm{mmol})$ in toluene $(10 \mathrm{~mL})$ was added a solution of $\left\{\left(\mathrm{Me} \mathrm{Si}_{2}\right)_{2} \mathrm{CH}\right\}_{2} \mathrm{Sr}(\mathrm{THF})_{2}(0.23 \mathrm{~g} 0.42 \mathrm{mmol})$ in THF (10 mL) followed by a solution of $\mathrm{BH}_{3} \cdot \mathrm{SMe}_{2}(0.4 \mathrm{~mL}, 0.80 \mathrm{mmol})$. After stirring for $1 \mathrm{~h}$, the solution was concentrated in vacuo to $10 \mathrm{~mL}$. Upon cooling $\left(5^{\circ} \mathrm{C}\right)$ colourless crystals of 4 suitable for X-ray crystallography were deposited. Isolated yield: 0.34 g, 84\%. Anal. Calcd. $\mathrm{C}_{42} \mathrm{H}_{92} \mathrm{~B}_{4} \mathrm{O}_{4} \mathrm{P}_{2} \mathrm{Si} 4 \mathrm{Sr}$ (966.33): C 52.20, H 9.60\%. Found C 52.00, H 9.47\%. ${ }^{1} \mathrm{H}\left\{{ }^{11} \mathrm{~B}\right\}$ NMR $\left(d_{8}-\mathrm{THF}, 25^{\circ} \mathrm{C}\right): \delta 0.08\left(\mathrm{~s}, 36 \mathrm{H}, \mathrm{SiMe}_{3}\right), 0.67\left(\mathrm{~d},{ }^{2} \mathrm{~J}_{\mathrm{PH}}=15.1 \mathrm{~Hz}, 2 \mathrm{H}, \mathrm{CHP}\right), 0.81\left(\mathrm{~d},{ }^{2} \mathrm{JPH}_{\mathrm{PH}}=\right.$ 11.0 Hz, 12H, BH 3 ), 1.77 (m, 8H, THF), 3.62 (m, 8H, THF), 7.16-7.19 (m, 6H, ArH), 7.77 (m, 4H, ArH). ${ }^{13} \mathrm{C}\left\{{ }^{1} \mathrm{H}\right\}$ NMR $\left(d_{8}-\mathrm{THF}, 25{ }^{\circ} \mathrm{C}\right): \delta 3.72\left(\mathrm{~d},{ }^{3} J_{\mathrm{PC}}=1.9 \mathrm{~Hz}, \mathrm{SiMe}_{3}\right), 11.60(\mathrm{~d}$, $\left.{ }^{1} J_{\mathrm{PC}}=2.9 \mathrm{~Hz}, \mathrm{CHP}\right), 26.46$ (THF), 68.38 (THF), 127.85 (d, $\left.J_{\mathrm{PC}}=7.7 \mathrm{~Hz}, \mathrm{ArC}\right), 128.14$ $(\mathrm{ArC}), 133.15\left(\mathrm{~d}, J_{\mathrm{PC}}=6.7 \mathrm{~Hz}, \mathrm{ArC}\right), 144.32\left(\mathrm{~d}, J_{\mathrm{PC}}=37.4 \mathrm{~Hz}, \operatorname{ArC}\right) .{ }^{11} \mathrm{~B}\left\{{ }^{1} \mathrm{H}\right\} \mathrm{NMR}\left(d_{8^{-}}\right.$ THF, $\left.25{ }^{\circ} \mathrm{C}\right): \delta-31.5\left(\mathrm{~d}, \mathrm{br},{ }^{1} \mathrm{~J}_{\mathrm{PB}}=61 \mathrm{~Hz}\right) .{ }^{31} \mathrm{P}\left\{{ }^{1} \mathrm{H}\right\}$ NMR $\left(d_{8}-\mathrm{THF}, 25{ }^{\circ} \mathrm{C}\right): \delta-16.4(\mathrm{~m}, \mathrm{br})$.

Crystal Structure Determinations of 2a, 2b, 2c, 3 and 4: For 2a, 2b, 2c, and 3 measurements were made at $150 \mathrm{~K}$ on an Oxford Diffraction (Agilent Technologies) Gemini A Ultra diffractometer, using CuK $\alpha$ radiation $(\lambda=1.54184 \AA)$ for $\mathbf{2 a}$ and MoK $\alpha$ radiation $(\lambda$ 
$=0.71073 \AA)$ otherwise. For 4 measurements were made using synchrotron radiation $(\lambda=$ $0.6889 \AA$ ) at beamline I19 of Diamond Light Source; because of rapid decomposition in the $\mathrm{X}$-ray beam, the data collection was interrupted, with minor adverse impact on precision of the results, but $91 \%$ coverage of the unique set of data was achieved. Cell parameters were refined from the observed positions of all strong reflections. Intensities were corrected semiempirically for absorption, based on symmetry-equivalent and repeated reflections. The structures were solved by direct or dual-space methods and refined on $F^{2}$ values for all unique data; Table S1 in the Supporting Information gives further details. All non-hydrogen atoms were refined anisotropically, and C-bound $\mathrm{H}$ atoms were constrained with a riding model, while B-bound $\mathrm{H}$ atoms were freely refined; $U(\mathrm{H})$ was set at 1.2 (1.5 for methyl groups) times $U_{\mathrm{eq}}$ for the parent C atom. Disorder in the four THF co-ligands of both $\mathbf{3}$ and $\mathbf{4}$ and uncoordinated solvent of $\mathbf{2} \mathbf{b}$ was successfully modelled with the aid of restraints on geometry and displacement parameters, while the disordered THF of $\mathbf{2 a}$ was treated by the SQUEEZE procedure of PLATON. ${ }^{12}$ Programs were Oxford Diffraction CrysAlisPro, Rigaku CrystalClear and Bruker APEX3 for data collection and processing, and programs of the SHELX family for structure solution, refinement, and molecular graphics. ${ }^{13}$ 


\section{References}

1. $\quad$ E. L. Gamble and P. Gilmont, J. Am. Chem. Soc. 1940, 62, 717-721.

2. N. R. Thompson, J. Chem. Soc. 1965, 6290-6295.

3. (a) L. D. Schwartz and P. C. Keller, Inorg. Chem. 1971, 10, 645-647. (b) J. W. Gilje, K. W. Morse and R. W. Parry, Inorg. Chem. 1967, 6, 1761-1765. (c) M. R. Anstey, M. T. Corbett, E. H. Majzoub and J. G. Cordaro, Inorg. Chem. 2010, 49, 8197-8199.

4. (a) A.-M. Fuller, A. J. Mountford, M. L. Scott, S. J. Coles, P. N. Horton, D. L. Hughes, M. B. Hursthouse and S. J. Lancaster, Inorg. Chem. 2009, 48, 11474-11482. (b) K. Izod, J. M. Watson, W. Clegg and R. W. Harrington, Inorg. Chem. 2013, 52, 1446-1475. (c) P. K. Majhi, A. Koner, G. Schnakenburg, Z. Kelemen, L. Nyulászi and R. Streubel, Eur. J. Inorg. Chem. 2016, 3559-3573. (d) F. Dornhaus, M. Bolte, H.-W. Lerner and M. Wagner, Eur. J. Inorg. Chem. 2006, 1777-1785. (e) V. L. Rudzevich, H. Gornitzka, V. D. Romanenko and G. Bertrand, Chem. Commun. 2001, 1634. (f) F. Dornhaus and M. Bolte, Acta Crystallogr. Sect. E 2006, 62, m3573m3575.

5. (a) H. Nöth and S. Thomas, Eur. J. Inorg. Chem. 1999, 1373-1379. (b) R. H. Less, H. R. Simmonds, S. B. Dane and D. S. Wright, Dalton Trans. 2013, 42, 6337-6343. (c) S. R. Daly, B. J. Bellott, D. Y. Kim and G. S. Girolami, J. Am. Chem. Soc. 2010, 132, 7254-7255. (d) D. Y. Kim and G. S. Girolami, Inorg. Chem. 2010, 49, 4942-2948. (e) A. C. Dunbar and G. S. Girolami, Inorg. Chem. 2014, 53, 888-896. (f) S. R. Daly, B. J. Bellott, M. A. Nesbit and G. S. Girolami, Inorg. Chem. 2012, 51, 6449-6459. (g) S. R. Daly, P. M. B. Piccoli, A. J. Schulz, T. K. Todorova, L. Gagliardi and G. S. Girolami, Angew. Chem. Int. Ed. 2010, 49, 3379-3381. (h) S. R. Daly, D. Y. Kim, Y. Yang, J. R. Abelson and G. S. Girolami, J. Am. Chem. Soc. 2010, 132, 2106-2107. (i) S. R. Daly, D. Y. Kim and G. S. Girolami, Inorg. Chem. 2012, 51, 7050-7065. (j) S. 
R. Daly and G. S. Girolami, Inorg. Chem. 2010, 49, 4578-4585. (k) S. R. Daly and G. S. Girolami, Chem. Commun. 2010, 46, 407-408. (l) S. R. Daly and G. S. Girolami, Inorg. Chem. 2010, 49, 5157-5166.

6. (a) A. J. Blake, T. V. Fetrow, Z. J. Theiler, B. Vlaisavljevich and S. R. Daly, Chem. Commun. 2018, 54, 5602-5605. (b) T. V. Fetrow, R. Bhowmick, A. J. Achazi, A. V. Blake, F. D. Eckstrom, B. Vlaisavljevich and S. R. Daly, Inorg. Chem. 2020, 59, 4861.

7. L. J. Morris, M. S. Hill, M. F. Mahon, I. Manners and B. O’Patrick, Organometallics in press: https://dx.doi.org/10.1021/acs.organomet.0c00008.

8. R. D. Shannon, Acta Crystallogr. Sect A. 1976, 32, 751-767.

9. K. Izod, C. Wills, W. Clegg and R. W. Harrington, Inorg. Chem. 2007, 46, 43204325.

10. S. Harder, S. Müller and E. Hübner, Organometallics 2004, 23, 178-183.

11. M. R. Crimmin, A. G. M. Barrett, M. S. Hill, D. J. MacDougall, M. F. Mahon and P. A. Procopiou, Chem.-Eur. J. 2008, 14, 11292-11295.

12. A. L. Spek, Acta Crystallogr. Sect. C 2015, 71, 9-18.

13. (a) CrysAlisPro, Agilent Technologies, Oxford, UK, Version 1.171.36, 2011. (b) CrystalClear, Rigaku Corporation, Tokyo, Japan, 2011. (c) APEX3, Bruker AXS Inc., Madison, USA, Version 2018.7-2, 2018. (d) G. M. Sheldrick, Acta Crystallogr. Sect. A 2015, 71, 3-8. (e) G. M. Sheldrick, Acta Crystallogr. Sect. A 2008, 64, 112-122. 